\title{
Prevention of Oedema Disease in Weaned Piglets by Vaccination
}

\author{
M. STAREK, G. BILKEI \\ Bilkei Consulting, Dübendorf, Switzerland \\ Received November 18, 2002 \\ Accepted June 17, 2004
}

\begin{abstract}
Starek M., G. Bilkei: Prevention of Ooedema Disease in Weaned Piglets by Vaccination. Acta Vet. Brno 2004, 73: 225-227.

In order to prove the effect of vaccination against postweaning oedema disease, a trial was performed in a large Croatian pig production unit, with high prevalence of postweaning oedema disease. The trial animals were either vaccinated (group one, $\mathrm{n}=275$ ) with a VT2e-toxoid vaccine at 1 week of age (with $12.5 \mu \mathrm{g}$ inactivated VT2e toxin per pig), and at 3 weeks of age (with $25 \mu \mathrm{g}$ inactivated VT2e toxin), or were placebo treated (group two, $\mathrm{n}=274$ ). Postweaning performance of piglets and serological status against VT2e toxin were evaluated.

Vaccination significantly $(p<0.05$ ) affected nursery weight gains (group 1: $302 \pm 32$ g; group 2: $276 \pm 42 \mathrm{~g}$ ). Mortality revealed significant $(p<0.01)$ differences between the vaccinated (group $1: 0.5 \%$ ) and non-vaccinated pigs (group $2: 7.9 \%$ ); fattening weight gain did not differ significantly $(p>0.05)$ between the groups (group 1:741 $\pm 42 \mathrm{~g}$ vs. group 2: $706 \pm 44 \mathrm{~g}$ ). There was a significant rise of serological OD values due to vaccination in the vaccinated animals $(p<0.01)$.
\end{abstract}

Swine, Escherichia coli, weaning, mortality, weight gain

Weaning has been recognised as one of the most stressful challenges of the piglet's life (Shanks 1938). Postweaning Escherichia (E.) coli- caused problems can be subcategorised into postweaning diarrhoea (PWD), oedema disease (ED), postweaning wasting (PWW) and haemorrhagic gastroenteritis (HGE) (Bölcskei et al. 1995). Ooedema disease has often been caused by haemolytic F18 pilus positive $E$. coli $\mathrm{O} 139$ that produce verotoxin $2 \mathrm{e}$ (VT2e, Moon et al. 1999). Verotoxigenic E. coli colonise the intestine via F18 pilus (Wils on and Francis 1986). A VT2e-toxoid vaccine was found to be effective against ED (Awad Masalmeh et al. 1989). The objective of the present study was to determine the effect of a VT2e-toxoid vaccine against ED under field conditions.

\section{Materials and Methods}

A trial was performed in the large Croatian pig production unit, with high losses due to postweaning ED. E. coli were serotyped for O139 by slide-agglutination tests in Vet Invest Zagreb (Croatia). Analysis of the isolates was performed in Vet Invest Zagreb (Croatia) by multiplex PCR assay for detecting genes for Shiga-like toxin type 11 and fimbrial adhesins F18 ab, ac according to B os worth and Casey (1997). Amplified products were electrophoresed in $2 \%$ agarose gel, stained with ethidium bromide, and examined under ultraviolet illumination. DNA fragment lengths were verified by a digested $£$-DNA standard run simultaneously. Control for DNA reference strains was included in each reaction. Test sensitivity (Se) was $95.2 \%$; specificity (Sp) $90.5 \%$. Seropositivity was monitored by an indirect ELISA that was used to detect specific anti-VT2e antibodies in serum obtained every sampling time from the same animals (30 pigs [identified by ear tags] in each group). VT2e-toxoid in $\mathrm{pH} 9.0$ carbonate puffer was applied directly to ELISA plates at $4{ }^{\circ} \mathrm{C}$ overnight. The plates were incubated with $0.05 \%$ Tween $20,1 \%$ bovine serum albumin in PSB-T-BSA for 1 hour. Serum samples were applied in 1:200 dilutions in PSB. Antibodies were detected with peroxidase-conjugated rabbit anti-swine immunoglobulins in PSB-T-BSA. Further processing took place according to Johansen et al. (1997). Colour was allowed to develop for $20 \mathrm{~min}$. Optical density (OD) was measured at $490 \mathrm{~nm}$ minus $650 \mathrm{~nm}$ by dual wavelength endpoints. The effect of vaccination on the serum level of VT2e-specific antibodies was assessed by the rise in optical density (OD) values. An experimental toxoid vaccine was produced as described by MacLeod and Gyles (1991) and Johansen et al. (1997).

Address for correspondence:

PhD. Dr. med. vet. G. Bilkei

Bilkei Consulting

Raubbühlstrasse 4

CH-8600 Dübendorf

Phone: + 4118200226

Switzerland

E-mail:bilkei.consulting@gmx.com

http://www.vfu.cz/acta-vet/actavet.htm 
Two randomised blind parallel treatment groups of piglets (weaning age 28 days) were formed. The animals were treated in consent with animal care regulations of Croatia and Switzerland.

Group 1, G1 $(\mathrm{n}=275)$ piglets were intramuscularly vaccinated at 1 week of age with $12.5 \mu \mathrm{g}$ and at 3 weeks of age with $25 \mu \mathrm{g}$ of inactivated VT2e toxin.

Group 2, G2 $(\mathrm{n}=274)$ piglets were given placebo.

Average daily nursery weight gain during 4 weeks after weaning (NADG), nursery mortality due to ED (EDNM), fattening weight gain until slaughter (FADG) and serological response to vaccination were evaluated.

GLMM (general linear mathematical model) and REML (reference manual) procedures of the statistical package of Genstat 5, Oxford, Clarendon and Fisher's exact test were used to analyse data. For time aspects (such as the exact age of the piglets at the time of vaccination) and proportion of piglets dying for ED a logistic regression model was used. For ADG from weaning to the end of the nursery period a linear regression model was used. The effect of the sow (and the interaction between treatment and sow) and the effect of initial weight were included as random components, but had no significant influence on nursery weight gain (NADG), mortality due to ED (EDNM) and fattening weight gain (FADG). Weight gain in the finisher period was analysed by the model including weight at last weighing, treatment effect, age of the animal, the effect of age and the effect of weight at weaning, and the effect of group. The change in OD-values from first vaccination to the end of the nursery period was analysed by paired $t$-test.

\section{Results and Discussion}

Vaccination significantly $(P<0.05)$ affected NADG $(\mathrm{G} 1: 302 \pm 32 \mathrm{~g} ; \mathrm{G} 2: 276 \pm 42 \mathrm{~g})$; mortality revealed significant $(P<0.01)$ differences between the vaccinated $(\mathrm{G} 1: 0.5 \%)$ and non-vaccinated pigs (G2: 7.9\%); FADG did not differ significantly $(p>0.05)$ between the groups (G1:741 $\pm 42 \mathrm{~g}$ vs. G2: $706 \pm 44 \mathrm{~g}$ ) (Table 1). There was a significant rise of serological OD values due to vaccination in G1 $(p<0.01)$ (Table 2). The control pigs seropositivity shows the infectious pressure due to VT2e bearing $E$. coli in this unit. There was no effect of vaccination on growth performance in the fattening period. This indicates that pigs whose growth rates are suppressed during the postweaning period are able to recover and gain satisfactorily during the fattening period.

Table one

The effect of vaccination on nursery weight gain, mortality, fattening weight gain

in a large pig production unit

\begin{tabular}{|ccccc|}
\hline Group & $\mathrm{n}$ & NADG g & EDNM \% & FADG g \\
\hline 1 & 275 & $302 \pm 32 \mathrm{a}$ & $0.5 \mathrm{~A}$ & $741 \pm 42 \mathrm{~ns}$ \\
\hline 2 & 274 & $276 \pm 42 \mathrm{~b}$ & $7.9 \mathrm{~B}$ & $706 \pm 4 \mathrm{~ns}$ \\
\hline
\end{tabular}

Table 2

The effect of vaccination on VT2e specific antibodies (OD)

in a large pig production unit

\begin{tabular}{|cccccc|}
\hline Group & $\mathrm{n}$ & T 1 & T & T 3 & T 4 \\
\hline 1 & 275 & $0.22 \pm 0.01 \mathrm{~A}$ & $1.11 \pm 0.01 \mathrm{~B}$ & $1.72 \pm 0.01 \mathrm{~B}$ & $0.75 \mathrm{~B} \pm 0.01 \mathrm{~A}$ \\
\hline 2 & 274 & $0.21 \pm 0.02$ & $0.14 \pm 0.01 \mathrm{a}$ & $0.35 \mathrm{~b} \pm 0.01$ & $0.28 \mathrm{~b} \pm 0.01$ \\
\hline
\end{tabular}

Legend (Table 1 and 2)

$\begin{array}{llll}\text { NADG: } & \text { average daily nursery weight gain } & \text { ns: } & \text { non significant } \\ \text { EDNM: } & \text { nursery mortality due to ED } & \text { Test }(\mathrm{T}) 1: & \text { before first vaccination } \\ \text { FADG: } & \text { fattening weight gain until slaughter } & \text { T 2: } & \text { at weaning (28 days of age) } \\ \text { OD: } & \text { optical density } & \text { T 3: } & \text { at the end of nursery period } \\ \text { a, b: } & \text { difference is significant }(p<0.05) & & \text { (from weaning to an age of 8 weeks) } \\ \text { A, B: } & \text { difference is significant }(p<0.01) & \text { T 4: } & \text { at an age of 4 month }\end{array}$

In the present study we decided to define "death caused by oedema disease" only cases with growth of heamolytic E. coli $\mathrm{O} 139$ bearing pilus F18 and revealing the for ED typical gross pathological changes. 
The present results are consistent with the findings of Awad Masalmeh et al. (1988), B osworth et al. (1996), Johansen et al. (1997), and Ken and Bilkei (2003) and indicate that vaccination with purified VT2e-toxoid can successfully prevent ED caused piglet losses under field conditions in weaned pigs.

\section{Prevence edémové choroby vakcinací odstavených selat}

K prokázání účinku vakcinace proti edémové chorobě po odstavu byl proveden pokus ve velkém chorvatském chovu prasat s vysokou prevalencí této nemoci. Pokusná selata byla bud" vakcinována (skupina $1, \mathrm{n}=275)$ VT2e-toxoid vakcínou týden po narození $(12.5 \mu \mathrm{g}$ inaktivovaného VT2e toxinu), tři týdny po narození (25 $\mu \mathrm{g}$ inaktivovaného VT2e toxinu), či jim bylo podáno placebo (skupina $2, \mathrm{n}=274$ ). Byl sledován přírůstek selat a provedeno sérologické vyšetření protilátek proti VT2e toxinu.

Vakcinace signifikantně $(p<0.05)$ zvýšila př́růstky (skupina 1: $302 \pm 32 \mathrm{~g}$; skupina 2: $276 \pm 42 \mathrm{~g}$ ); signifikantní byl rozdíl v mortalitě $(p<0.01)$ mezi vakcinovanými (skupina 1: $0,5 \%$ ) a nevakcinovanými prasaty (skupina 2: 7,9\%); váha po výkrmu se mezi skupinami signifikantě nelišila $(p>0,05)$, (skupina 1: $741 \pm 42$ g proti skupině 2: $706 \pm 44 \mathrm{~g}$ ). U vakcinovaných prasat nastal signifikantní nárůst $(p<0,01)$ optické density séra.

\section{References}

AWAD-MASALMEH, M, SCHUH, M, KOFER, J, QUAKYI, E 1989: Verification of the protective effects of toxoid vaccine against oedema disease of weaned piglets in an infection model. Dtsch Tierärztl Wschr 96: 419421

BÖLCSKEI, A, BILKEI, G, BIRO, O, CLAVADETSCHER, E, GOOS, TH, WALLER, C, STELZER, P 1995: Management der E. coli-bedingten Faktorenkrankheiten nach dem Absetzen der Ferkel. Berl Münch Tierärztl Wschr 109: 108-111

JOHANSEN, M, ANDERSEN, LO, JORSAL, SE, THOMSEN, LK, WADDEL, TE, GYLES, CL 1997: Prevention of oedema disease in pigs by vaccination with verotoxins 2 E Toxoid. Can J Vet Res 61: 280-285

KEN, C, BILKEI, G 2003: Effect of vaccination and of a phytogenic feed additive on postweaning mortality due to Escherichia coli and on piglet performance. Vet Rec 153: 302-303

MACLEOD, DL, GYLES, CL 1991: Immunisation of pigs with a purified Shiga - lile toxin II variant toxoid. Vet Microbiol 29: 309-318

MOON, HW, HOFFMANN, LJ, CORNICK, NA, BOOTHER, SL, BOSWORTH, BT 1999: Prevalences of some virulence genes among Escherichia coli isolates from swine presented to a diagnostic laboratory in Iowa. J Vet Diagn Invest 11: 557-560

SHANKS, PL 1938: An unusual condition affecting the digestive organs of the pigs. Vet Rec 50: 356-316

WILSON, RA, FRANCIS, DH 1986: Fimbriae and enterotoxins associated with Escherichia coli serogroups isolated from pigs with colibacillosis. Am. J Vet Res 47: 213-217 